\title{
Process characterization and nutrient profiling of traditional meat products of the Borana communities in northern Kenya
}

\begin{abstract}
Meat is a highly valued food among the Borana pastoralist community in Northern Kenya. Borana produce a number of traditionally preserved beef and goat meat products. Although these traditional products are widely appreciated, there is concern about their nutritional quality, especially because some of them are preserved with fats and other ingredients. Thus, the objectives of this study were to characterize the traditional meat product processes and to establish their nutrient profile and shelf life stability. Samples were collected from study sites and analyzed in the laboratory. Results showed that moisture contents ranged from 3.3 to $6.1 \%$, crude protein contents ranged from 55.8 to $72.5 \%$ while crude fat ranged from 9.4 to $13.3 \%$. Calcium, magnesium, iron, potassium, ranged from $35.8-110 \mathrm{mg} / 100 \mathrm{~g}$, $52.8-60.7 \mathrm{mg} / 100 \mathrm{~g}, 4.5-7.4 \mathrm{mg} / 100 \mathrm{~g}$ and $701-826 \mathrm{mg} / 100 \mathrm{~g}$ respectively, while riboflavin and niacin ranged from $0.03-0.14 \mathrm{mg} / 100 \mathrm{~g}$ and $2.38-3.82 \mathrm{mg} / 100 \mathrm{~g}$ respectively. The fatty acid composition showed that beef and goat koche contained good amount of monounsaturated oleic acid at mean levels of $37.2 \%$ and $39.2 \%$ respectively. The peroxide value, acid value and thiobarbituric acid levels were below the value associated with meat spoilage during the expected shelf life. Hence the traditional processed meat products could improve the food security of Borana communities due to its excellent nutrient source for a balanced meal.
\end{abstract}

Keywords: traditional, meat, drying, nutrition composition, quality, Borana, Marsabit
Volume 6 Issue 2 - 2018

\author{
Buke Dabasso,' Anselimo Makokha,' Arnold \\ Onyango,' Hassan Roba, ${ }^{2}$ Julius Maina' \\ 'Jomo Kenyatta University of Agriculture and Technology, Kenya \\ ${ }^{2}$ National Museum of Kenya, Kenya
}

Correspondence: Buke Dabasso, Jomo Kenyatta University of Agriculture and Technology; Nairobi, Kenya, Tel +254-71 0-482642,Email buke.galma@gmail.com

Received: February 21, 2018 | Published: April 06, 2018
Abbreviations: PV, peroxide value; TBA, thiobarbituric acid; ANOVA, analysis of variance; LSD, least significant difference; MDA, malondialdehyde

\section{Introduction}

Livestock products, specifically, milk and meat occupy a special place in the Borana diet for a variety of reasons including availability, preference, tradition and prestige. Cattle are Kenya's most important source of red meat, supplying by value about $80 \%$ of the nation's ruminant off take for slaughter ${ }^{1}$ whereas goats are mainly kept for meat production for household consumption. Goat meat accounts for more than $70 \%$ of all meat consumed in pastoral households in Marsabit. ${ }^{2}$ Borana people produce different type of traditional meat products from Boran cattle (Bos indicus) and goat (Capra hircus) for nutritional supplement and snacks for special occasions and to meet seasonal fluctuation in the available protein in their diet. They have developed unique recipes and storage methods that increase products shelf-life under the traditional pastoral production environment. Meat is a concentrated nutrient source essential for optimal growth and development. The importance of meat in the diet is due to the fact that it is highly nutritious and provides proteins of high biological value. ${ }^{3}$

There are many types of traditional meat products which were produced and processed by the Borana. Due to frequent utilization and consumption of meat products, many traditional preservation techniques such as striping, drying and use of heat were practiced by Borana to increase the quality and shelf life of these products. $\mathrm{As}^{4}$ pointed out, processing helps in producing varieties and convenient meat products in order to meet various lifestyle requirements while preservation supported by processing extends the shelf-life of meat and meat products.

A dried cooked traditional meat product is processed by Borana community in Northern Kenya. It used to be common food among pastoralist in the olden days when they relied on meat and milk as staple food. It has been a popular and cherished product since time immemorial. The dried cooked traditional meat is similar to nyirinyiri made from camel meat by the Somali community. It is also similar to other many traditional dried meat products in various regions around the world like pastrami in Turkey, Egypt and Armenia, charque in South America, kilishi in Nigeria and West Africa, qwantain Ethiopia and biltong in South Africa. ${ }^{5}$ While the nutritional composition may vary somewhat according to breed, feeding regimen, season and meat cut, in general lean red meat has low fat content, is moderate in cholesterol and rich in protein and many essential vitamins and minerals. ${ }^{6}$

Processing is important in the context of human nutrition since it refers to applying technology to improve or maintain quality, extend shelf life (preserving) and prepare meat for consumption. ${ }^{7}$ In the case of dried traditional meat, various stages of processing are applied. The dried traditional meat, Koche is made from particular parts of muscles of sirloin and silverside steak, from beef or goat carcass. This dried traditional meat can be classified as dehydrated food as moisture is reduced at different levels and using different ways. $\mathrm{As}^{8}$ described, meat drying is preservation techniques used to prolong shelf-life of raw meat which reduces storage and makes handling stress-free by reducing size and weight. Knowing that meat is a perishable product, Borana women, first remove and sort out any surface fat, 
fatty tissues and connective tissues which contribute to fast spoilage. Then the meat is sliced into thin strips to dry for two or three days to dry. Additionally, the meat is deep fried to evaporate more moisture while preservation is also enhanced by seasonings such as salt, sugar and cardamom. Dehydration is one of the oldest forms of food preservation and can be achieved through many different processes and the main type of dehydrated meat is jerky.

Traditional meat products are still prestigious and highly valued products among the Borana at household level. They are mainly prepared for social cultural events like weddings, ceremonies and show cased in cultural and tourism festivals. Therefore, these traditional products have potential to be promoted as income generating activities for the producers. These meat products are still processed and preserved by traditional methods that lack technological advancement. $\mathrm{As}^{10}$ observed, traditional methods of meat preservation such as drying, smoking, brining and canning have been replaced elsewhere by new preservation techniques such as chemical, bio preservative and non-thermal techniques. Despite the fact that these traditional products are widely consumed locally, there is concern about their quality and acceptability as there is no documented information about their nutritional and quality status. Up scaling production of traditional meat products is constrained by lack of understanding of its nutrient and chemical contents. ${ }^{11}$ Observed that the preserved meat products from the pastoral area are not standardized and that most of the process and product parameters are currently unknown. Thus, the objectives of this study were to characterize the traditional meat product processes and to establish their nutrient profile and shelf life stability of processed meat products among the Borana community in Marsabit County, Kenya.

\section{Materials and methods}

\section{Study site}

The traditional meat products were prepared and produced in Marsabit County, Kenya.

\section{Sample collection}

Fifty samples of different traditional meat products were collected from Marsabit processed by local women groups. The meat cut was from steak of silverside, sirloin and topside. Samples of products included: Beef koche, Goat meat koche, pounded meat fonntuma and pounded meat mix with barley fonntuma garbu. The preparation of the products took one to three days and samples were transported to Jomo Kenyatta University of Agriculture and Technology food science laboratory for chemical and nutritional analysis packed in universal bottles and stored in a cool box while on transit.

\section{Laboratory analysis}

Moisture content: Moisture was determined in a drying oven as per. ${ }^{12}$ About $2 \mathrm{~g}$ of sample was accurately weighed into a moisture dish and transferred to an oven previously heated to temperatures of $105^{\circ} \mathrm{C}$ and drying done for 1 hour. The final weight of the sample was taken after the drying period and cooling in a desiccator. The flour residue was then reported as total solids and loss in weight as moisture.

Crude protein: Crude protein was determined using the Kjedahl Method. ${ }^{12}$ About $1 \mathrm{~g}$ of sample was weighed into a digestion flask together with a catalyst composed of $5 \mathrm{~g}$ of $\mathrm{K}_{2} \mathrm{SO}_{4}$ and $0.5 \mathrm{~g}$ of $\mathrm{CuSO}_{4}$ and $15 \mathrm{ml}$ of concentrated $\mathrm{H}_{2} \mathrm{SO}_{4}$. The mixture was heated in a fume hood till the digest color turned blue signifying the end of the digestion process. The digest was cooled, transferred to a $100 \mathrm{ml}$ volumetric flask and topped up to the mark with distilled water. A blank digestion with the catalysts and acid, but no sample, was also made. Ten(10) $\mathrm{ml}$ of diluted digest was transferred into a distilling flask and washed with about $2 \mathrm{ml}$ distilled water. $15 \mathrm{ml}$ of $40 \% \mathrm{NaOH}$ was added and this was also washed with about $2 \mathrm{ml}$ distilled water. Distillation was done to a volume of about $60 \mathrm{ml}$ distillate. The distillate was titrated using $0.02 \mathrm{~N}-\mathrm{HCl}$ to an orange color of the mixed indicator which signified the end point.

Crude fat: Crude fat was determined using soxhlet extraction method. ${ }^{12}$ The Soxhlet extraction method which gives intermittent extraction of oil with excess of fresh organic solvent was used. About $5 \mathrm{~g}$ of sample was weighed into extraction thimble and the initial weight of the extraction flask taken. Fat extraction was done using petroleum ether in Soxhlet extraction apparatus for 16 hours. The extraction solvents were evaporated and the extracted fat dried in an oven for about $15 \mathrm{~min}$ before the final weight of the flask with extracted fat was taken.

Crude ash: Crude ash was determined by dry ashing. ${ }^{12}$ About $3 \mathrm{~g}$ of dried sample was ashed in the crucible at $550^{\circ} \mathrm{C}$ for 5 hours or until the ash is white or greyish-white. The percentage of ash in the sample was determined as follows:

$$
\{[\mathrm{Wt}(\text { Ash }+ \text { Crucible })-\mathrm{Wt}(\text { Crucible })] / \text { sample }(\mathrm{g})\} \text { X100 . }
$$

Crude fibre: Crude fibre was determined as per. ${ }^{12}$ Approximately $2 \mathrm{~g}$ of the sample was weighed into a $500 \mathrm{ml}$ conical flask. About $200 \mathrm{ml}$ of boiling $1.25 \% \mathrm{H}_{2} \mathrm{SO}_{4}$ was added and boiling done for 30 minutes under reflux condenser. It was then dried in an oven at $105^{\circ} \mathrm{C}$ in a porcelain dish to a constant weight (W1). Incineration was done in a muffle furnace at $550^{\circ} \mathrm{C}$ for $3 \mathrm{hrs}$, the dish was then cooled in a desiccator and the final weight (W2) taken.

\section{Carbohydrate was calculated by difference:}

Carbohydrates $=100-($ Proteins + Lipids + Fiber + Ashes $)$

The gross energy was calculated, according to $\mathrm{WHO}^{13}$ by the following formula:

$\mathrm{GE}=[($ Proteins $\times 4)+($ Lipids $\times 9)+($ Carbohydrates $\times 4)] \times$ dry matter $/ 100$

Where GE is the Gross Energy.

Quality indices: Free fatty acids (\% of oleic acid) were analyzed by using the method of ${ }^{14}$ and changes in biogenic amine such as TMA-N, TVB-N (mg N /100g). The $\mathrm{pH}$ of meat was measured in a slurry made with distilled water (1:10) and measured using $\mathrm{pH}$ meter (Hanna $\mathrm{pH}$ meter 213). Titratable acidity was determined by titrating with $0.1 \mathrm{~N} \mathrm{NaOH}$ to an end point. Peroxide Value (PV) were expressed as milli-equivalents of peroxide oxygen $/ \mathrm{kg}$ of sample, was determining according to the method of Egan. ${ }^{15}$ The Thiobarbituric acid (TBA) was analyzed according to Egan et al. ${ }^{16}$ and expressed as $\mathrm{mg}$ of malondialdehyde (MDA) $/ \mathrm{kg}$.

Determination of mineral and vitamin composition: The quantification of iron, zinc, calcium, magnesium, potassium and sodium, was done by atomic absorption spectrometry using AAS (Shimadzu AA-6200). ${ }^{17}$ Retinol and $\alpha$-tocopherol were analysed by a Shimadzu LC10A VP Series liquid while the water-soluble vitamins were also determined by Shimadzu LC-10A VP Series liquid 
chromatography fitted with a photo-diode detector (Waters 2996) as described in the method by AOAC. ${ }^{18}$

Determination of fatty acid composition: The fatty acid profile was determined by gas chromatography system (GC-9A Shimadzu Co., Tokyo, Japan). The extraction of the total lipids was done by a modification of the method Ekinci et al. ${ }^{19}$

\section{Data analysis}

The data obtained were subjected to analysis of variance (ANOVA) to evaluate processing effect on the proximate and chemical characteristic of traditional meat products. When significant difference was observed between the samples for a parameter, the ANOVA was complemented by LSD (Least Significant Difference) test to identify the means that are different. Statistical significance was measured at $(\mathrm{P}<0.05)$ using IBM SPSS version 19.0 software and Microsoft office excel was also used to generate tables. The data were expressed as means \pm standard error.

\section{Results and discussion}

\section{Characterization of traditional product processing}

Koche: Koche is a dried, pea sized cooked product made from goat meat and beef carcass. The meat was sliced into stripes and suspended on a rope at room temperature to dry for one to two days. When expected dryness was attained the stripes were removed from rope and cut into pea sized pieces. The pieces were then put in a pot, salt was sprinkled while cooking on low heat as it evaporates all the steams till it dries. Then oil was added for deep frying with continued stirring until it turns dark brown. Then, it was removed from fire for cooling overnight or more than ten hours. The cooled product was then stored in oil either in aluminum/stainless steel jug or traditional

Table I Nutrient profile of the traditional food products (grams/l00 g)' storage.

Fonn tuma (pounded meat): Fonn tuma a dried, roasted and pounded product was made from beef. The meat was sliced into tiny stripes and suspended on a rope at room temperature to dry for three days. When expected dryness was attained the stripes were removed from rope and roasted over a jiko (hot charcoal) then pounded using wooden mortar and pestle until the meat is grounded. Then it's deep fried, while continued stirring was done. Three spoonsful of sugar, half tea spoon of salt and grounded cardamom was added. The heat used for cooking was medium and when the products turned golden brown it was removed from fire and cooled overnight or approximately ten hours and stored in closed jug (aluminum/stainless steel or traditional container).

Fonntumma garbu (pounded meat with barley): fonntuma garbu is a mixture of fonntuma, (pounded meat) and barley (hordeum vulgaris). Barley grains are winnowed, soaked in hot water and pounded to remove the hull. The dehulled grains were roasted until golden brown and mixed with fonntuma while deep frying. Cooling was done for subsequent storage.

Table 1 shows proximate composition of traditional meat products. Results revealed the processed meat products of less than $7 \%$ while protein percent in processed meat products $55.8-72.5 \%$. The gross energy values in the processed meat products were also high.

Table 2 contains the quality indices of processed traditional meat products. There was no significant different among treatment on $\mathrm{pH}$ values. In this study, the Peroxide Value (PV) of the processed samples was $1.8-2.6 \mathrm{mEq} / \mathrm{kg}$. These values are within the value for prevention and control of rancidity development in meat. PV in all samples was below $25 \mathrm{mEq} / \mathrm{kg}$, which is considered as limit of acceptability in fatty foods. ${ }^{20}$

\begin{tabular}{lllll}
\hline Proximate profile \% & Beef $($ koche) & Goat (koche) & Beef pounded & $\begin{array}{l}\text { Mix beef and } \\
\text { barley }\end{array}$ \\
\hline Ash & $1.7 \pm 0.1$ & $3.4 \pm 0.2^{\mathrm{b}}$ & $1.9 \pm 0.2$ & $2.8 \pm 0.6$ \\
Crude fibre & $1.9 \pm 0.2$ & $1.5 \pm 0.2^{\mathrm{b}}$ & $2.2 \pm 0.3$ & $4.1 \pm 0.4^{\mathrm{b}}$ \\
Protein & $65.7 \pm 3.7$ & $72.5 \pm 1.7$ & $65.2 \pm 2.0$ & $55.8 \pm 1.2$ \\
Moisture content & $5.5 \pm 1.1$ & $4.6 \pm 0.3$ & $3.3 \pm 0.3$ & $6.1 \pm 1.7$ \\
Crude fat & $10.2 \pm 1.4$ & $9.4 \pm 1.0$ & $13.3 \pm 0.9$ & $10.3 \pm 0.8$ \\
Carbohydrates & $13.5 \pm 2.4$ & $8.7 \pm 1.2$ & $15.6 \pm 1.4$ & $21.6 \pm 2.2$ \\
Kcal//00g & $413.9 \pm 5.9$ & $404.7 \pm 5.7$ & $435.2 \pm 4.6$ & $399.4 \pm 8.4$
\end{tabular}

'Means of samples analyzed in triplicate \pm standard error.Values in the same row with the same superscript are significantly different at $(\mathrm{P}<0.05)$.

Table $2 \mathrm{pH}$ and fat quality indices of traditional meat in

\begin{tabular}{lllll}
\hline Quality Indices & Beef (koche) & Goat (koche) & Beef pounded & $\begin{array}{l}\text { Mix beef and } \\
\text { barley }\end{array}$ \\
\hline $\mathrm{PH}$ & $5.90 \pm 0.18$ & $6.1 \pm 0.08$ & $5.7 \pm 0.05$ & $5.85 \pm 0.03$ \\
Peroxide value $\mathrm{mEq} / \mathrm{kg}$ & $2.4 \pm 0.8$ & $2.5 \pm 0.8$ & $2.6 \pm 0.8$ & $1.8 \pm 0.8$ \\
TBA mg MDA/kg & $0.52 \pm 0.01$ & $0.4 \pm 0.02$ & $0.5 \pm 0.02$ & $0.32 \pm 0.02$ \\
Acidity \% & $0.01 \pm 0.00$ & $0.01 \pm 0.00$ & $0.0 \pm 0.00$ & $0.00 \pm 0.00$ \\
Free fatty acid \% & $2.55 \pm 0.01^{\mathrm{b}}$ & $1.37 \pm 0.02$ & $0.80 \pm 0.02$ & $0.38 \pm 0.00^{\mathrm{b}}$ \\
\hline
\end{tabular}

'Means of samples analyzed in triplicate \pm standard error.Values with the same superscript are significantly different at $(\mathrm{P}<0.05)$. 
Free fatty acids values of processed meat products were $0.38-2.55 \%$ oleic acid. These values are and below the threshold for rancidity detection in dried cooked meat. Thiobarbituric acid (TBA) values expressed as $\mathrm{mg}$ of malondialdehyde (MDA) $/ \mathrm{kg}$ of processed products were $0.32-0.52(\mathrm{MDA}) / \mathrm{kg}$ hence, it was within the acceptable range. TBA value is routinely used as an index of lipid oxidation in meat products in store ${ }^{21}$ and the rancid flavor is initially detected in meat products between TBA values of 2.0. ${ }^{22}$
Table 3, shows mineral composition of the traditional meat products. The levels of potassium 701.3-826.6 mg/100g, iron 4.57.4, calcium $35.8-110.0 \mathrm{mg} / 100 \mathrm{~g}$ and sodium $158.3-364.4 \mathrm{mg} /$. The processed traditional meat also contains vitamins.

The traditional meat fatty acids composition is presented in Table 4. The predominant acids in the meat were, oleic $16.4-39.2 \%$, palmitic $19.3-33.2 \%$, and linoleic $2.5-13.5 \%$.

Table 3 Mineral and vitamin content $(\mathrm{mg} / \mathrm{l} 00 \mathrm{~g})$ of traditional meat

\begin{tabular}{|c|c|c|c|c|}
\hline Minerals and vitamins & Beef (koche) & Goat (koche) & Beef pounded & $\begin{array}{l}\text { Mix beef and } \\
\text { barley }\end{array}$ \\
\hline Calcium & $71.6 \pm 0.6$ & $51.8 \pm 1.4$ & $110.0 \pm 3.4^{b}$ & $35.8 \pm 1.7^{b}$ \\
\hline Iron & $7.3 \pm 0.2 b$ & $4.5 \pm 0.1$ & $7.4 \pm 0.2 b$ & $5.5 \pm 0.2$ \\
\hline Zinc & $4.6 \pm 0.1$ & $5.7 \pm 0.3$ & $4.7 \pm 0.1$ & $2.9 \pm 0.1$ \\
\hline Potassium & $702.5 \pm 8.9$ & $773.8 \pm 17.3$ & $701.3 \pm 9.2$ & $826.6 \pm 4.8$ \\
\hline Magnesium & $53.0 \pm 0.6$ & $60.7 \pm 1.1$ & $52.8 \pm 0.5$ & $59.0 \pm 1.1$ \\
\hline Sodium & $229.8 \pm 3.5$ & $364.4 \pm 8.2^{b}$ & $265.2 \pm 4.3$ & $158.3 \pm 1.8^{b}$ \\
\hline Thiamin & $0.15 \pm 0.01$ & $0.06 \pm 0.02$ & $0.19 \pm 0.04$ & $0.14 \pm 0.01$ \\
\hline Riboflavin & $0.07 \pm 0.01$ & $0.03 \pm 0.01$ & $0.11 \pm 0.03$ & $0.14 \pm 0.05$ \\
\hline Niacin & $3.69 \pm 0.20$ & $3.82 \pm 0.13$ & $3.67 \pm 0.09$ & $3.4 I \pm 0.23$ \\
\hline Pyridoxine & $0.48 \pm 0.08$ & $0.49 \pm 0.02$ & $0.35 \pm 0.04$ & $0.35 \pm 0.07$ \\
\hline Retinol ( $\mu g / g)$ & $19.54 \pm 0.35^{b}$ & $36.16 \pm 0.7 I^{b}$ & $17.40 \pm 1.32^{\mathrm{b}}$ & $28.68 \pm 2.38^{b}$ \\
\hline$\alpha$-tocopherol $(\mu \mathrm{g} / \mathrm{g})$ & $5.19 \pm 0.32^{b}$ & $2.52 \pm 0.12^{\mathrm{b}}$ & $4.72 \pm 0.75$ & $3.60 \pm 0.4 I$ \\
\hline
\end{tabular}

'Means of samples analyzed in triplicate \pm standard error.Values with the same superscript are significantly different at $(\mathrm{P}<0.05)$.

Table 4 Fatty acid composition of traditional meat products (\%) and SEM'

\begin{tabular}{llllllll}
\hline & $\begin{array}{l}\text { Lauric } \\
\text { CI 2:0 }\end{array}$ & $\begin{array}{l}\text { Myristic } \\
\text { CI4:0 }\end{array}$ & $\begin{array}{l}\text { Palmitic } \\
\text { CI6:0 }\end{array}$ & $\begin{array}{l}\text { Stearic } \\
\text { CI8:0 }\end{array}$ & $\begin{array}{l}\text { Oleic } \\
\text { CI 8:I }\end{array}$ & $\begin{array}{l}\text { Linoleic } \\
\text { CI 8: n-6 }\end{array}$ & $\begin{array}{l}\text { Linolenic } \\
\text { C I 8:3n-3 }\end{array}$ \\
\hline $\begin{array}{l}\text { Pounded } \\
\text { meat }\end{array}$ & 3.2 & II & 28.3 & 11.6 & 26.8 & 4 & 1.9 \\
Beef koche & 0.4 & 1.4 & 33.2 & 7.8 & 37.2 & 13.3 & 1.6 \\
Goat koche & 0.4 & 2.3 & 32.3 & 5.8 & 39.2 & 13.5 & 1.9 \\
Beef barley & 2.8 & 9.1 & 23 & 9.7 & 23.1 & 2.9 & 2 \\
Goat barley & 2.6 & 7.5 & 19.3 & 6.8 & 16.4 & 2.5 & 1.4 \\
\hline
\end{tabular}

Istandard Error of Means.

Traditional meat processing mainly applied drying as the preservation method. The drying process was enhanced by the striping of the meat. Striped meat was observed to dry quickly. The drying was monitored by constantly checking so that it was at the desired level, and does not affect the final product. Together with heating process, drying is an important stage in traditional meat processing as it contributes to the keeping quality of the final products. Critical Processing Stages for Shelf-Stability and Safety for dried meat products is the drying step. ${ }^{23,24}$

The drying process facilitated the reduction of moisture content to less than $7 \%$ in all the processed products. Such low moisture level is effective in preventing spoilage, and hence facilitating preservation. The drying also led to an increase in concentration of other nutrient components such as protein.
The proximate composition shows that traditional meat is a shelf stable product as it has low moisture content, similar with the study done by ${ }^{25}$ who opined that the profile of the proximate composition of the danbunama proved the product to be a very shelf stable product, where its low moisture percentage promotes its ability to stay at room temperature in spite of its high level of protein and fat combined.

The traditional meat products have high protein content due to processing which has increased the dry matter while there was reduction in moisture content. ${ }^{26}$ observed that intermediate moisture meat are meats low in moisture content and contain three to four times the raw protein equivalent. Similarly ${ }^{27}$ illustrated that cooking caused moisture content decrease resulting in increased nutrient concentration, particularly in the protein content, and a consequent rise in energy values in cooked meat. 
Other ingredients added to the meat during processing also contributed to the nutrition value and quality of the traditionally processed meat. The seasonings added to traditional meat products were salt, cardamom and sugar, which are not only important in preservation, but also improved the organoleptic properties to the products and shelf stability. Salt and sugar both have preservative effect. Sodium chloride $(\mathrm{NaCl})$ in foods can be a source of osmotic stress by decreasing water activity whereas sugars have the capabilities to bind with moisture and reduce water activity in foods. They are generally used in dried meat processing as a source of sugars or carbohydrates to enhance flavor, reduce harshness of salt and lower water activity. ${ }^{23}$

The addition of barley contributed to an increase in starch and crude fiber in the processed meat products. ${ }^{28}$ reported high crude fiber content in meat product (suya) as a result of high level of fibre in some of the constituents of the ingredient used in preparing the meat products whose source was from plants. Crude fibre is important in diet as it contribute towards better digestion. Barley is rich partly in soluble dietary fibres, mainly $\beta$-glucan and that scientific evidence shows adding whole-grain barley products to food can contribute to lowering serum cholesterol. ${ }^{29}$ The gross energy content in cooked traditional meat was also high at $416 \mathrm{kcal} / 100$ gwhich was similar to beef jerky and dried smoked meat. ${ }^{30}$

Peroxide value (PV), is used in evaluation of the early stages of oxidation of the oils and oil containing products. The result in this study indicates that the PV levels were below recommended value for increased risk of development of rancidity this is in agreement with findings by ${ }^{31}$ that the acceptable limits of PV is 10 to $20 \mathrm{meq} / \mathrm{Kg}$ sample. Free fatty acid (FFA) formation is by hydrolysis reactions within lipids and their accumulation can be used as an indicator of lipid breakdown. ${ }^{32}$

The TBA test measures a secondary product of lipid oxidation, malonaldehyde. The TBA of $0.32-0.52 \mathrm{mg}$ (MDA) $/ \mathrm{kg} / \mathrm{kg}$ of traditional meat product in this study did not exceed critical value of $3 \mathrm{mg}$ (MDA) $/ \mathrm{kg}$ of meat at which rancidity is virtually detected. ${ }^{33}$ Similarly, ${ }^{34}$ reported results obtained for kilishi, which were within the acceptable limits of the maximum level of TBA value, indicating good quality of the kilishi samples during storage, which was 1-2 $\operatorname{mgMDA} / \mathrm{kg}$.

Meat and meat products are also important sources of minerals in the diet. The mineral content in the dried meat were also higher in comparison to those in the raw meat. Beef has almost all-important minerals for human nutrition. In addition, the iron in beef is absorbed 3 to 5 times faster than when originating from vegetables. ${ }^{35}$ Traditional meat contains sufficient number of vitamins $a^{36}$ described that meat and meat products are important sources of all the B-complex vitamins including thiamin, riboflavin, niacin, biotin and vitamins B6.

Fatty acid content found in traditional meat are Palmitic (C16:0) 19.3-33.2\%, Oleic acid (C18:1) 16.4-39.2\%, and Linoleic (C18:2) $2.5-13.5 \%$ in different products. Beef and goat koche was also found to have higher content of oleic $37.2 \%$ and $39.2 \%$ respectively and linoleic $13.3 \%$ and $13.5 \%$, respectively indicating that the traditional meat products do provide important essential fatty acids. The fat content in meat and meat products is a matter of concern in the diets. In meat it is highly variable depending on species, origin, feeding system and the cut. ${ }^{37}$ In addition, $30 \%$ of the Fatty Acid content in conventionally produced beef is composed of oleic acid (C18:1), a monounsaturated FA (MUFA) that elicits a cholesterol-lowering effect among other healthful attributes. ${ }^{37}$

\section{Conclusion}

Traditional meat processing among the Borana was accomplished through heating, drying and addition of salt and sugar. The traditional meat products were nutrient rich products, where the concentration of nutrients was enhanced by the drying process. The keeping quality of the products was good, as all the rancidity indices including the Peroxide Value, Acidity and Thiobarbituric acid (TBA) were below the value associated with increased risk of rancidity.

These findings signify that the traditional products meat have the potential to provide important levels of key nutrients including monounsaturated fatty acids which are beneficial to health. There is potential to upscale the production of these traditional meat products. This will contribute to increased income among the community.

\section{Acknowledgements}

The Author acknowledges and thank RELOAD project for funding the study.

\section{Conflict of interest}

The author declares that there is no conflict of interests regarding the publication of this paper.

\section{References}

1. Behnke R, Muthami D. The contribution of livestock to the Kenyan economy. IGAD Livestock Policy Initiative. UK: Odessa Centre, Great Wolford; 2011. 62 p.

2. Schwartz HJ, Abdullah N Said. The ecological role of the goat in pastoral production systems in Northern Kenya. Spain: Simposio Internacional de la Explotacion Caprina en Zonas Aridas, At Fuerteventura, Islas Canarias; 1985.

3. Roberta Boe. Oxidative stability, lipid composition and nutritional value of ruminant meat as affected by animal feeding system, sex and common household treatments. Triennio accademico. 2011. 230 p.

4. SharmaBD, Kondaiah N. Development of Buffalo meat samoa and evaluation of its storage in low vacuum Family Park under frozen condition. J Vet Pub Health. 2005;(3):59-62.

5. Bender Arnold. Meat and meat products in human nutrition in developing countries. Italy: FAO Food and Nutrition Paper; 1993.

6. Williams PR. Nutritional composition of red meat. Nutrition Diet. 2007;64(suppl 4):S113-S119.

7. Casey NH. Goat meat in human nutrition. Proceedings of the V International Conference on Goats, Indian Council of Agricultural Research, New Delhi; 1992.

8. Javeed Akhtar, Ram Krishna Pandey. Meat drying technology and drying characteristics of meat and meat products. IJAPSA. 2015;1(8):1-6.

9. Presswood H. Lipid stability of dehydrated beef strips stored in two packaging types. Faculty of Natural Resources and Agricultural Science. 2012. $48 \mathrm{p}$

10. Mekonnen A. Major Causes of Meat Spoilage and Preservation Techniques: A Review. Food Science and Quality Management. $2015 ; 41: 1-15$. 
11. Imungi JK. The Present Status of Meat Processing and Preservation in the Pastoral Regions of Kenya. Food Science and Quality Management. 2014;32:42-50.

12. AOAC. Official methods of analysis. 16th ed. USA: Association of official analytical chemists. 1995;3(6):131-140.

13. WHO/FAO. Food Energy-Methods of Analysis and Conversion. Italy: FAO Food and Nutrition Paper, No 77. FAO, Rome. 2003. 93 p.

14. Egan HR, Kirk S, Sawyer R. Clinical, Hematological and Biochemica Health Benefit Effects of Hibiscus sabdariffa Lin Dried Calyces Beverage in Human. Food and Nutrition Sciences. 2016;7(5).

15. Egan H, Kirk RS, Sawyer R. Pearson's chemical analysis of foods. 8th ed. New york: Churchill Livingstone, Medical division of Longman group Ltd; 1981.591 p.

16. Egan H, Kirk RS, SawyerR. Pearson's chemical analysis of foods. 9th ed 1997;(4):609-634.

17. Kirk S, Ronald S. Pearson's Composition and Analysis of foods. 9th ed. UK: Longman Scientific and Technical; 1991. 708 p.

18. AOAC. Official Methods of Analysis of the Association of Official Analytical Chemists. Arlington: AOAC International; 1996.

19. Ekinci R, Kadakal C. Determination of seven water-soluble vitamins in tarhana, A traditional Turkish cereal food, by High-Performance Liquid Chromatography. Acta Chromatographical. 2005;15:289-297.

20. Pearson D. The Chemical Analysis of Foods. 7th ed. UK: Churchil Livingstone, London; 1976. 575 p.

21. Evranuz E. The effects of temperature and moisture content on lipid peroxidation during storage of un-blanched salted roasted peanuts: shelf life studies for un-blanched salted roasted peanuts. Int J Food Sci Technol.1993;28:193-199.

22. Raharjo S, Sofos JN. Methodology for measuring malonaldehyde as a product of lipid peroxidation in muscle tissues: A review. Meat Sci. 1993;35(2):145-169.

23. Gray JI, Pearson AM. Rancidity and warmed-over flavor. In: Pearson AM, Dutson TR, editors. Advances in meat research. USA: Van Nostrand Company; 1987:221-269.

24. USDA. Principles of preservation of shelf-stable dried meat products. New York: United State Department of Agriculture, Food Safety and Inspection Service; 2005. p. 1-15.
25. Gunter Heinz, Peter Hautzinger. Meat processing technology for small-to medium-scale producers. FAO. 2007:1-50.

26. Ogunsola OO, Omojola AB. Nutritional evaluation of a dehydrated shredded meat product, (danbunama). Pakistan Journal of Nutrition. 2008;7(4):554-556

27. Egbunike GN, Okunbanjo AO. Effects of processing upon the quality of Nigerian meat products. Livestock Production Sci. 1999;59(2-3):55-163.

28. Apata ES, Kuku IA, Apata OC, et al. Evaluation of Suya (Tsire)-An Intermediate Moisture Meat Product in Ogun State, Nigeria. Journal of Food Research. 2013;2(1):87.

29. Aman P. Cholesterol-lowering effects of barley dietary fiber in humans: scientific support for a generic health claim. Scandinavian Journal of Food Nutrition. 2006;50(4):173-176.

30. USDA. US Department of Agriculture, Agricultural Research Service USDA National Nutrient Database for Standard Reference; 2009.

31. Mgbemere VN, Akpapunam MA, Igene JO. Effect of groundnut flour substitution on yield, quality and storage stability of Kilishi-a Nigerian indigenous dried meat product. African Journal of Food Agriculture Nutrition and Development. 2011;11(2):4718-4738.

32. Perkins E. Volatile odor and flavor components formed in deep frying. In: Erickson M, editor. Urbana, IL: AOCS Press Deep Frying, Chemistry, Nutrition and Practical Applications; 2006. p. 51-56.

33. Wong DWS. Lipids. In: Mechanism and Theory in Food Chemistry. New York: Van Nostrand Reinhold, Springer; 1989. p. 1-47.

34. Iheagwara MC, Okonkwo TM. Influence of Storage Duration on Stability and Sensorial Quality of Dried Beef Product (Kilishi). J Food Process Technology. 2016;(7):574.

35. Pereira PM. Meat nutritional composition and nutritive role in the human diet. Meat Sci. 2013;3(3):586-592.

36. Almeida de Oliveira1 E, Sampaio A. Chemical and Fatty acid composition of different cuts cooked or uncooked from yearling bulls fed oil sources. Acta Scientiarum Animal Sciences. 2015;37(2):187-194.

37. Daley CA, Abbott A, Doyle PS, et al. A review of fatty acid profiles and antioxidant content in grass-fed and grain-fed beef. Nutrition journal. 2010;9:10 